DOI 10.37882/2500-3682.2021.03.22

\title{
СТЕФАН ГЕОРГЕ И ГЕНРИХ БЁЛЛЬ: ТВОРЧЕСТВО КАК СЦЕНАРИЙ ИДЕНТИЧНОСТИ И ПОЛИТИЧЕСКОГО ПРОРОЧЕСТВА ДЛЯ ГЕРМАНИИ
}

\section{STEFAN GEORGE AND HEINRICH BÖLL THE ART AS THE SCENARIO FOR GERMAN IDENTITY AND POLITICAL PREDICTION \\ F. Fidarova}

Summary: The paper discusses the conceptual problems of Stefan George and Heinrich Böll's art through the prism of diachronic approach to literature. The analysis is based on the idea that the poet and the writer act as a breaking point for the social and political forces of Germany, and that they have changed cultural challenge. We still know few things about the political ideology that has affected the works of George. But it has found a response and an understanding in Böll's works.

Keywords: ideology, the New Reich, symbolist, language competition, identity.
75 -летие победы во Второй мировой войне настойчиво возвращает нас к немецким терминам, текстам и их авторам, которые желали Германии возрождения после проигранной Первой мировой войны. Поэт Стефан Георге тоже поддержал идею Третьего рейха Меллера ван ден Брука через понятие Новый рейх и не мог представить, что его судьбоносный термин для возрождения немецкой нации потомки окрестят началом великой катастрофы. Этот термин окрылил национал-социалистов, они сделают его орудием мести за проигранную войну, навяжут немцам чуждую культуру и развяжут новую Великую войну. Писатель Генрих Бёлль, как участник этой войны, на себе испытал опасность политических терминов, разрушающих и политическую культуру, и культуру.

Первый немецкий поэт-символист Стефан Георге (Stefan George 1868-1933) вернул в нашей стране свой поэтический авторитет, хотя он его никогда и не терял. В коммунистической России о Георге просто забыли, поэтому его не пришлось и запрещать [Георге, 2009: 335].

В 2009 году в нашей стране вышел сборник стихов С. Георге "Седьмое кольцо» (нем. „Der siebente Ring"). Почему в нашей литературе произошло такое забвение поэта, почти не исследуется, оно не известно массовому читателю.

При обозрении обширного поэтического наследия
Фидарова Фатима Казантемировна К.культурологии, дочент, Московский государственный университет имени М.В. Ломоносова fidarova@inbox.ru

Аннотация: Предлагаемая статья рассматривает теоретические проблемы творчества С. Георге и Г. Бёлля в диахроническом подходе к литературным произведениям. В основу настоящего анализа положено убеждение, что поэт и писатель являются точкой преломления социальных и политических сил Германии, изменивших культурный вызов времени. Политическая идеология, которая определяла творчество поэта-символиста Георге, до сих пор в нашей стране остается почти неизвестной, однако она нашла ответ и прозрение в творчестве Бёлля.

Ключевые слова: идеология, Новый рейх, символист, языковая конкуренция, идентичность.

С. Георге и литературе о нем создается впечатление, что речь идет не об одном авторе-художнике, символисте, а об авторе-мыслителе с идеологической направленностью. Такая тенденция в творчестве Георге вполне понятна, поскольку он в 1889-1891 гг. учился в Берлине на философском факультете. Георге «поклонник Ницше и поэт» [Георге, 2009: 338].

В 1890 году в Германии вышла в свет первая книга С. Георге -«Гимны». В. Летучий указывает, что именно с «неё и начинается немецкий символизм, и в коротком стихотворении «Морской берег» уже наличествует классический набор символистских атрибутов: ладан, алтарь, плющ, лавр, лебеди, чайки, тайна, - не так уж много слов, но за каждым определенный символ, и символ этот ещё сослужит службу не одному поколению все новых и новых символистов» [Георге, 2009: 338]. «Ибо, как писал немецкий поэт-символист Иоганн Гюнтер (1886-1978), особенность каждого убежденного символиста - создавать из реальных предметов и понятий комплекс личных переживаний» [Георге, 2009: 339].

Свои стихи Георге называет «зеркальным отражением души» [Георге, 2009: 339]. Вокруг Георге сплачиваются поэты, художники, историки, архитекторы, философы, появляется поэтическая школа «школа Георге». Теоретической основой для школы стал журнал «Листки искусства» („Blätter für Kunst“) С. Георге, который начал выходить с 1892 года. 
В душе поэта-символиста зрели и другие символы, которые затрагивали глубинные основы политической культуры Германии, следовательно, и культуры. Культуру в этом контексте следует понимать как систему, охватывающую самые разнообразные формы и стороны общественных отношений.

Георге стал символистом и в общественно-политической речи в кризисную эпоху для Германии - после проигранной Первой мировой войны. В немецкой политической речи этого периода благодаря писателям Х. Гримму и Меллеру ван ден Бруку в 1923 и 1926 гг. появились новые политические термины «народ без пространства», «Третий рейх». Эти термины указывают нам на «соотнесенность таких понятий, как история языка и национальная история» [Юдина, 2001: 66]. Ханс Гадамер тоже определил эту соотнесенность: «Лучший способ отобразить крушение общества в кризисную эпоху - это наблюдать за изменениями его языка» [Гадамер, 1991: 50]. Однако «смена общественных формаций, сохранение существующих общественных отношений, дееспособность соответствующих государственных институтов, проведение в жизнь политических решений неосуществимо без порождения и восприятия соответствующих текстов, то есть без языковой коммуникации» [Юдина, 2001: 67].

Георге и порождает текст с новым символическим содержанием, который четко указывал на поиск и необходимость фюрера для Нового рейха:

Der sprengt die Ketten, fegt auf Trümmerstätten Die Ordnung, geißelt die Verlaufenen heim Ins ewige Recht wo Großes wiederum groß ist, Herr wiederum Herr. Zucht wiederum Zucht; .er heftet Das wahre Sinnbild an das völkische Banner Er führt durch Sturm und grausige Signale Des Frührots seiner Treuen Schar zum Werk Des wachen Tags und pflanzt das neue Reich [Linden, 1944: 339].

Он рвет оковы, приводит в порядок груды развалин, Бичом загоняет домой заблудших и растерянных К вечной справедливости, где великие опять обретают величие,

Хозяин снова хозяин, дисциплина вновь дисциплина. Он крепит верный символ на народное знамя

И ведет через бурю и страшные знамения

Ранней зари свой преданный отряд на дело

Дня бодрствования и сеет семена Нового Рейха [Крейг, 1999: 73].

На уровне текста, создававшегося Георге в 1928 году, смысловой потенциал его символов-терминов получает дальнейшее развитие, вектор которых направлен в будущее Германии. Георге «смотрел дальше и нашел путь к Рейху» [Wulf, 1963: 30].

Продолжая эту мысль, И. Вульф указывает, что Геор- ге, словно пророк своего народа, оглядывается назад и предвидит будущее.. Именно Георге «спасет наши старые и новые мечты в своем Рейхе» [Wolters, 1930: 527].

Политический романтизм 1920-х годов в Германии содержит в себе конкретный пример идеологического направления исторической эпохи: требование создания Нового, Третьего рейха во главе с фюрером, культурной основой которого непременно должна была быть расовая чистота немцев. Георге является ревностным сторонником этого нового культурно-политического вызова времени.

Следует указать, что стихотворение Георге «Новый рейх» („Das neue Reich“) вышло в 1928 году в последнем поэтическом сборнике поэта с одноименным названием. Разумеется, в этом тексте стихотворения могут возникнуть проблемы с переводом, связанные с понятием Reich, поскольку у него несколько значений, а именно: государство, империя, рейх, царство, мир, область, сфеpa.

Однако характерным элементом общественно-политического дискурса Германии этого периода являлись четко выраженные националистические термины: Третий рейх, фёлькиш идеология, расовая теория, народ без пространства. Именно эти термины подкрепляли идею поиска достойного вождя, фюрера, который смог бы объединить расколотую и униженную немецкую нацию, они постепенно стали занимать центральное место и в протестном движении партий. Следовательно, Георге, говоря о Новом рейхе, четко указывает на Третий рейх, поскольку Второй рейх Бисмарка уже не существовал. Кроме того, в пятой строке своего стихотворения Георге указывает и на фёлькиш знамя (нем. völkische Banner).

Однако в русском переводе «народный», «народное знамя» понятие völkisch теряет свой послевоенный смысл, поскольку это слово „народный“ означает в шовинистическом значении.

Очевидно, что политическая борьба партий в этот период в Германии сопровождалась борьбой и в области семантики, и новые термины в стихотворении Георге подтверждают эту мысль и тенденцию. «Языковая конкуренция и политическое противостояние порождают новые типы текстов, общественные движения оказывают существенное влияние на коммуникативные процессы» [Юдина, 2001: 68]. Свою идентичность с будущим обновленным государством националистические поэты и писатели Германии выражали через текст и новые термины, которые были приведены выше.

Кроме того. Георге уже перед Первой мировой войной в стихотворении «Детям моря» (1913) говорил об «особой крови светловолосых» [Keller, 1970: 55]. По мнению Келлера, такая точка зрения сближает Георге с пропагандистами расовой теории. 
Таким образом, мы можем утверждать, что стихотворения Георге «Новый рейх» („Das neue Reich“) и «Детям моря» четко выражали идентичность времени после Первой мировой войны.

Георге отказался сотрудничать с национал-социалистами, однако через свои новые символы-термины выразил требование нового времени и помог подготовить базу для их прихода. Георге умер в 1933 году в Швейцарии и ему не пришлось пожить в условиях Нового (Третьего) рейха, о котором он так страстно мечтал. Однако понятия из лексикона нацистов, которые вначале немцам казались сырыми, дикими словами, вдруг превратились в культурные слова. Согласно М. Бахтину, «культурное слово - преломленное сквозь авторитетный отстоявшийся medium слово» [Бахтин, 1994: 102].

Немецкий писатель Генрих Бёлль на себе испытал, что такое дух нового времени: Третий рейх, фёлькиш идеология, фюрер. Эти термины породили не только новые типы текстов с политическими требованиями, но также и новый тип фёлькиш писателей. Итогом их влияния станет не только крах Германского рейха, но они также приведут к культурному пробелу в немецкой культуре.

Таким образом, становление Бёлля как писателя, происходило в тот период исторического пути немецкой культуры, который, как было сказано, принято теперь называть культурным пробелом.

Роман Бёлля «Где ты был, Адам?» („Wo warst du, Adam“?) вышел в 1951 г. в Опладене. Именно это произведение принесло Бёллю огромный успех не только в Германии - роман был вскоре переведен во многих странах. Бёлль занял видное место среди писателей «Группы 47», которая объединяла молодых западногерманских писателей, а главной задачей для нее являлась резкая критика нацистской идеологии, милитаризма.

Бёлль начал поиск нового духовного пути для немецкой литературы через идентичность текста. Бёлль имел на это право, поскольку его личный опыт был глубок: учился в школе при нацистах, в мундире вермахта прошел войну, но в конце войны понял преступность нацистской авантюры и сдался в плен американцам.

Бёлль, в противоположность Георге, который мечтал о Новом рейхе с фюрером, стремился воспринятое во время Второй мировой войны показать как преступное и катастрофическое для настоящих и будущих поколений. Разобраться в мире немецкой послевоенной действительности значило для Бёлля - осмыслить ход и содержание военных действий Германии на захваченных территориях и показать трагизм затеянной нацистами авантюры.

«Где ты был, Адам?» - это роман о войне. Главные действия разворачиваются в последние месяцы войны, начиная с 1944 года. Автор погружает читателя вместе с отступающими немецкими войсками через Румынию, Венгрию и Чехословакию в трагизм ситуации, приближает его к пониманию того, что Германия стоит на пороге неминуемой капитуляции.

Автор не описывает нам жестокие и кровопролитные сражения, количество павших и пленных, однако каждое действие и событие в романе содержит в себе элемент великой приближающейся катастрофы. Драматизм, который показывает Бёлль в своем романе, усиливается через катастрофическую быстроту отступления немецких войск.

Роман начинается с цитаты-эпиграфа Теодора Хеккера (1879-1945), немецкого критика и публициста: И всемирная бойня может задним числом пригодиться. Скажем, для того, чтобы доказать свое алиби перед лицом Всевышнего. «Где ты был, Адам?» - «В окопах, Господи, на войне...» [Бёлль, 1996: 133].

Бёлль отвечает ему на этот вопрос вторым эпиграфом, словами Антуана де Сент-Экзюпери: Но война - это не подвиг, а лишь его дешевый суррогат. Война - это болезнь, эпидемия, вроде сыпняка [Бёлль, 1996: 133].

Несмотря на отступление немецких войск, жестокость концлагерной жизни продолжала свирепствовать: «В лагере было тихо, никаких признаков жизни, и только из труб крематория валил густой дым» [Бёлль, 1996: 231].

«Валил густой дым» означал, что, даже получив приказ об отступлении по курсу Великая Германия, район Австрия, начальник концлагеря Фильскайт приказал сжечь всех узников. На вопрос своего заместителя (он только что привез 67 человек для хора), где же узники лагеря, Фильскайт с усмешкой отвечал, что «никого не осталось, а не вывезли, хор только вывезут» [Бёлль, 1996: 232].

Жестокость Фильскайта для войны и ради войны усиливается и из-за его личного „несоответствия“ стандартам и нормам нордической расы.

Бёлль раскрывает нам эти глубокие переживания своего героя, поскольку расовую теорию Фильскайт воспринял как осуществление своих сокровенных идеалов: вступил в «гитлерюгенд», быстро сделал там карьеру, проглатывал все книги по расовым проблемам. Однако жизнь Фильскайта наполняется особым, личным трагизмом, когда началась война, «он упорно отказывался от «брони», рвался на фронт и добивался зачисления в эсэсовские части «Мертвая голова», но он был черноволос, мал ростом и явно принадлежал к пикническому типу» [Бёлль, 1996: 236].

Бёлль четко показывает, что не все немцы нашли себе опору в новом культурном требовании времени - в ра- 
совой теории. Как видно из приведенной цитаты, даже „немец“ и „расовая теория“ оказались взаимно исключающими друг друга понятиями. Бёлль раскрывает также в своем романе, что политическое пророчество с рейхом и фюрером, с которым Георге и Брук себя идентифицировали, привело к жестокой войне с концлагерями и газовыми печами для умерщвления людей.

Бёлль пытается вернуть своих соотечественников к осмыслению самой страшной катастрофы XX века - анализу войны, которая и в самой Германии привела к разрухе, развалинам и голоду. «Это было возвращение из войны, в окончание которой вряд ли еще кто-то верил» [Бёлль, 1996: 673].

Продолжая эту мысль, Бёлль пишет: «Итак, мы писали о войне и о возвращении домой, о том, что нашли дома, когда вернулись: о развалинах» [Бёлль, 1996: 673]. «Уводить современников в царство идиллии будет, так считали мы, жестокостью, слишком страшным окажется пробуждение; или, может, прикажете нам в жмурки играть?» [Бёлль, 1996: 674].

Когда Бёлль говорит, что «и глаза наши вспоминают кладбища, и глаза наши видят развалины, разрушенные города, города-кладбища», то совершенно очевидно, что он имеет в виду и Германию, и Россию [Бёлль, 1996: 677]. Романтики войны в Германии теперь молчат. Бёлль указывает на новое направление в литературе Германии: «Все это „литература о войне“, „литература развалин“ и „литература вернувшихся“» [Бёлль, 1996: 677].

Бёлль пытается также найти ответ, как искоренить понятие войны из нашего лексикона: «Никогда больше не было бы войны, если бы павшие в бою, которых очередной поезд умчал навстречу смерти, заговорили» [Böll, 2005: 57].
Г. Бёлль не только художник слова, но и политически ангажированный писатель Германии, предостерегает современные средства массовой информации от произвольного использования слова, ибо слова могут убивать. Бёлль подчеркивает, что «политику вершат словами, что именно слова сделали человека объектом политики и заставили его претерпеть все беды истории» [Бёлль, Т. 3: 643].

Таким образом, у нас есть достаточно оснований, чтобы увязать поиск нового духовного пути для немецкой литературы через идентичность текста двух великих писателей Германии. Георге поддержал идею Нового Третьего рейха для немцев, что привело к политическому краху Германского рейха и культурному пробелу. Свою идентичность с обновленным государством после проигранной Второй мировой войны писатель Бёлль также выражал через текст и новые термины.

В дискурсивном пространстве немецкой общественно-политической речи, после проигранной Первой мировой войны, появились новые типы текстов. Они стали порождением политического противостояния и языковой конкуренции поэтов и писателей Германии. Георге идентифицировал себя вслед за Бруком с новыми политическими терминами. Бёлль, напротив, показал их бессмысленный и опасный итог.

Мир двух выдающихся писателей Германии не замкнут, а многообразно пересекается и переплетается: поэт Георге своим идеологическим пророчеством нашел культурно-политическую опору в новых националистических терминах через новый тип текста, которые очень пригодились национал-социалистам. Писатель Г. Бёлль своим авторским словом предостерегает об опасности использования этих политических терминов, оказавших фатальное влияние на историческое и культурное развитие его страны и всего мира.

\section{(1)}

ЛИТЕРАТУРА

1. Бахтин М.М. Проблемы творчества поэтики Достоевского. М., 1994.

2. Бёлль Г. Собрание сочинений в 5-ти томах. Т. 1. М., 1996.

3. Гадамер Х.Г. Актуальность прекрасного. М., 1991.

4. Георге С. Седьмое кольцо. М., Водолей, 2009.

5. Крейг Г. Немцы. М., Ладомир, 1999.

6. Юдина Т.В. Теория общественно-политической речи. М., Московский университет, 2001.

7. Böll H. Das Vermächtnis. München, 2005.

8. Keller E. Nationalismus und Literatur. Bern und München, 1970.

9. Linden W. Deutsche Dichtung am Rhein. Ratingen, 1944.

10. Wolters F. Stefan George und die Blätter für die Kunst. Berlin, 1930.

11. Wulf J. Literatur und Dichtung im Dritten Reich. Mohn, 1963.

(с) Фидарова Фатима Казантемировна (fidarova@inbox.ru). 